\title{
The Role of C-Peptide as Marker of Cardiometabolic Risk in Women With Polycystic Ovary Syndrome: A Controlled Study
}

\author{
Sebastiao Freitas de Medeiros ${ }^{\mathrm{a}, \mathrm{b}, \mathrm{c}}$, Laura Camila Antunes Angelo ${ }^{\mathrm{a}}$, \\ Matheus Antonio Souto de Medeiros ${ }^{\mathrm{b}}$, Camila Regis Banhara ${ }^{\mathrm{b}}$, \\ Bruna Barcelo Barbosa ${ }^{b}$, Marcia Marly Winck Yamamoto ${ }^{b}$
}

\begin{abstract}
Background: The aim of this study was to examine the role of $\mathrm{C}$ peptide as a biological marker of cardiometabolic risk in polycystic ovary syndrome (PCOS).

Methods: This case-control study enrolled 385 PCOS patients and 240 normal cycling women. Anthropometric and clinical variables were taken at first visit. Fasting C-peptide, glucose, lipids, and hormone measurements were performed. Simple and multiple correlations between C-peptide and other variables associated with dysmetabolism and cardiovascular disease were examined.
\end{abstract}

Results: C-peptide was well correlated with several anthropometric, metabolic, and endocrine parameters. In PCOS patients, stepwise multiple regression including $\mathrm{C}$-peptide as the criterion variable and other predictors of cardiovascular disease risk provided a significant model in which the fasting C-peptide/glucose ratio, glucose, body weight, and free estrogen index (FEI) were retained (adjusted $\mathrm{R}^{2}=$ $0.988, \mathrm{~F}=7.161, \mathrm{P}=0.008$ ).

Conclusion: C-peptide levels alone or combined with C-peptide/ glucose ratio, glucose, body weight, and FEI provided a significant model to identify PCOS patients with higher risk of future cardiometabolic diseases.

Keywords: Polycystic ovary syndrome; C-peptide; Dyslipidemia; Dysglycemia; Cardiovascular disease

\section{Introduction}

Polycystic ovary syndrome (PCOS) expression, under the in-

Manuscript submitted December 15, 2017, accepted January 12, 2018

aDepartment of Gynecology and Obstetrics, Medical School, Federal University of Mato Grosso, Cuiaba, MT, Brazil

${ }^{\mathrm{b}}$ Tropical Institute of Reproductive Medicine, Cuiaba, MT, Brazil

${ }^{c}$ Corresponding Author: Sebastiao Freitas de Medeiros, Federal University of Mato Grosso, Cuiaba, MT, 78055-728, Brazil.

Email:de.medeiros@terra.com.br

doi: https://doi.org/10.14740/jocmr3325w fluence of multiple pathogenic mechanisms, presents hyperandrogenism, hyperinsulinemia, obesity and insulin resistance (IR) as the most prevalent findings $[1,2]$. Several markers of IR have been tested. An alternative marker for IR and beta-cell dysfunction, the connecting peptide (Pep-C), facilitates the assembly, folding and processing of insulin and is secreted in an equimolar ratio with this hormone from the pancreatic beta cell directly into the portal circulation [3]. As advantages, the C-peptide does not undergo hepatic first-pass metabolism and has a longer half-life than insulin. Therefore, its concentration in the blood is more stable, providing an accurate marker of pancreatic insulin secretion [4]. An increase in its levels suggests a worsened insulin resistant state.

C-peptide, initially considered an inactive molecule, has, currently, been shown to be a bioactive molecule that binds to the surface of several cell types, where it activates the calciumdependent intracellular signalling pathway [5]. In patients with type 1 diabetes mellitus (T1DM), C-peptide seems to have a protective effect on microvascular complications, prevents or decreases diabetes-induced glomerular changes and has an anti-inflammatory effect [6]. On the other side, a few studies suggest that high levels of C-peptide promote atherogenesis [7]. Further, in type 2 diabetes mellitus (T2DM), C-peptide has some pro-inflammatory properties in the process of atherosclerotic plaque formation, may induce vascular smooth muscle cell proliferation and has also been associated with the intimamedia thickness of the carotid artery $[7,8]$. A relationship between C-peptide concentrations and macrovascular complications in T2DM was also reported [9]. Additional data suggest that C-peptide might participate in the vascular inflammatory response and contribute to the development of cardiovascular disease (CVD) [10]. Whether C-peptide compares to other known biomarkers of insulin resistance in predicting future CVD or not is still a matter of debate $[10,11]$.

Currently, in the clinical setting, the C-peptide measurement has been limited to differentiating T1DM and T2DM, the identification of patients with maturity-onset diabetes of the young (MODY), the detection of absolute insulin deficiency, and monitoring pancreatic beta-cell function [12]. The role of C-peptide in predicting CVD in PCOS patients remains limited to helping to determine the degree of insulin resistance and $\beta$-cell function. The current study hypothesized that the fasting C-peptide concentration could be a useful marker of dysmetabolic and hormonal alterations in PCOS patients. This hypothesis was tested by comparing head-to-head fasting C- 
peptide to other already established clinical and biochemical predictors of future T2DM and CVD in PCOS patients.

\section{Methods}

The study enrolled 385 PCOS patients and 240 normal cycling women who attended at the Julio Muller University Hospital and Tropical Institute of Reproductive Medicine in Cuiaba, MT, Brazil, from January 2012 to December 2016, who had Cpeptide measured in blood. Every patient gave full-informed written consent by signing a form approved by the local Committee for Ethics in Research. Presences of infrequent bleeding, amenorrhea, clinical or biochemical hyperandrogenism, and polycystic ovary morphology were investigated and PCOS was diagnosed using the Rotterdam criteria [13]. The criteria used to exclude other hyperandrogenic conditions were as follows: non-classic 21-hydroxylase deficiency (17-hydroxyprogesterone $\leq 5 \mathrm{ng} / \mathrm{mL}$ ), $11 \beta$-hydroxylase deficiency (11-deoxycortisol $<8 \mathrm{ng} / \mathrm{mL}$ ), $3 \beta$-hydroxysteroid dehydrogenase deficiency (17-hydroxypregnenolone $<0.42 \mathrm{ng} / \mathrm{mL}$ ), hyperprolactinemia (prolactin (PRL) $<25 \mathrm{ng} / \mathrm{mL}$ ) and thyroid dysfunction (thyroxin stimulating hormone $0.35-4.2 \mu \mathrm{g} / \mathrm{dL}$ ) [14, 15]. Users of sex steroids or insulin-sensitizing agents over the last 6 months were also excluded.

Waist circumference (WC), hip circumference $(\mathrm{H})$, body weight (BW), body mass index (BMI), lean body mass (LBM), fat mass (FM), and conicity index (CI) measurement procedures were detailed in a previous study [16]. A BMI lower than 25 was considered a normal weight, 25 - 29.9 was considered overweight, and $30 \mathrm{~kg} / \mathrm{m}^{2}$ or higher was defined as obese [17]. The visceral adiposity index (VAI) was estimated using the equation: $\mathrm{WC} /(36.58+(1.89 \times \mathrm{BMI})) \times(\mathrm{TG} / 0.81) \times(1.52 / \mathrm{HDL}-\mathrm{c})[18]$.

For all of the biochemical and hormonal measurements, blood samples were collected between the third and fifth days of a spontaneous menstrual flow or in the case of amenorrhea at any day; in this case, the progesterone (P4) level was measured to certify that samples were collected in the follicular phase, and, in this case, the results were validated whenever the P4 levels were $\leq 2.0 \mathrm{ng} / \mathrm{mL}$ [14]. A chemiluminescence assay (Advia Centaur, Siemens Healthcare Diagnostics, UK) with a sensitivity of $0.21 \mathrm{ng} / \mathrm{mL}$, the coefficients of intra- and interassay variation were between $3.7-12.4 \%$ and $2.6-3.9 \%$ was used to measure P4. C-peptide was measured using a chemiluminescence assay (Elecsys 1010, Roche Diagnostics GmbH, Mannhein, German) with a sensitivity of $0.01 \mathrm{ng} / \mathrm{mL}$ and intraand inter-assay coefficients of variation between $3 \%$ and $5 \%$ in all of the concentration ranges. Sensitivity, working-range, and imprecision of other hormone measurements at the local laboratory were given elsewhere [16]. A hyperandrogenic state was defined when FAI was $\geq 6 \%$, the total testosterone was $\geq$ $2.08 \mathrm{nmol} / \mathrm{L}$, DHEAS was $6.7 \mathrm{nmol} / \mathrm{L}$, A was $\geq 8.7 \mathrm{nmol} / \mathrm{L}$, and the free $T$ was $\geq 0.027 \mathrm{pmol} / \mathrm{L}[14]$.

Glucose oxidase technique (Beckman glucose Analyses, Fullerton, CA, USA) was used to measure fasting glucose. Glycated hemoglobin was measured using the turbidimetric assay (Wiener Laboratories, Rosario, Argentina). Impaired fasting glucose (IFG) was defined by a fasting plasma glucose
(FPG) concentration of $>100 \mathrm{mg} / \mathrm{dL}(5.5 \mathrm{mmol} / \mathrm{L})$ and $<126$ $\mathrm{mg} / \mathrm{dL}(6.99 \mathrm{mmol} / \mathrm{L})$. Insulin resistance was defined by fasting insulin levels of $>12.2 \mu \mathrm{U} / \mathrm{mL}$ [19] and/or an HOMA-IR of $\geq 2.7$ [20]. HOMA-IR, HOMA \%B and HOMA S were calculated using the free HOMA 2 calculator software (Diabetes Trials Unit, Oxford, UK) [21]. Fasting $\beta$ cell responsiveness to glucose concentrations was estimated using the fasting C-peptide/fasting glucose ratio [22]. Hepatic insulin extraction was computed in the basal state as the molar ratio of the C-peptide to the insulin levels [4]. Total cholesterol (TC), triglycerides (TG), and high-density lipoprotein cholesterol (HDL-c) were measured using an enzymatic assay (Wiener Laboratories, Rosario, Argentina). Low-density lipoprotein cholesterol (LDLc) was calculated as follows: CT (HDL-C + TG/5) [23]. Lipid accumulation product (LAP) was calculated using (WC $(\mathrm{cm})$ - 58) $\times(\mathrm{TG}(\mathrm{mmol} / \mathrm{L}))[24]$.

The original data of each variable were initially submitted to the Grub's test to avoid the interference of outliers. After exclusion of the outlier data, the distribution was assessed by a Shapiro-Wilk test and those with a non-Gaussian distribution were transformed. The data that skewed to the right were linearized using a logarithmic transformation, and the data that skewed to the left were linearized using the square transformation. Prior to the analysis, the data were back-transformed into the original units. The results are presented as the mean and standard error of the mean (SEM). Differences between the two independent and continuous variables were assessed using Welch test. The relationship between the two variables was examined using the Pearson's correlation coefficient (r). A stepwise-multiple regression analysis was performed with C-peptide as the criterion variable and several anthropometric, endocrine, and metabolic variables as predictor variables. The decision for a predictive variable to be included in the model was $\mathrm{P} \leq 0.05$ in the simple linear correlation. All of the statistical procedures were performed with SPSS version 17 (SPSS Inc., Chicago, IL, USA). P-values $<0.05$ were considered statistically significant.

\section{Results}

As whole groups, the PCOS patients and the normal cycling women were, on average, $27.3 \pm 5.4$ and $30.2 \pm 4.9$ years old, respectively $(\mathrm{P}<0.001)$. Regarding PCOS patients, $116(30.1 \%)$ were of a normal weight, $120(31.2 \%)$ were overweight, and 149 (38.7\%) were obese. Among controls, 61.3\% were normal weight, $29 \%$ were overweight, and $9.7 \%$ were obese. The number of obese was significantly higher in PCOS $(\mathrm{P}<0.001)$. A total of 279 (72.5\%) PCOS patients had biochemical hyperandrogenism and 106 (27.5\%) had normal androgen levels. In normal cycling women, no one presented biochemical hyperandrogenism. IFG was found in $15.2 \%$ of the PCOS patients and in $3.9 \%$ of controls $(\mathrm{P}<0.001)$. Insulin resistance was present in $48.7 \%$ of the PCOS patients and in $11.6 \%$ of control patients $(\mathrm{P}<0.001)$. The baseline clinical, anthropometric, metabolic, and hormonal characteristics of PCOS patients and normal cycling women are compared in Table 1. The simple correlation of several independent variables with C-peptide 
Table 1. Clinical, Metabolic and Hormonal Baseline Characteristics of Normal Cycling Women and Polycystic Ovary Syndrome Patients

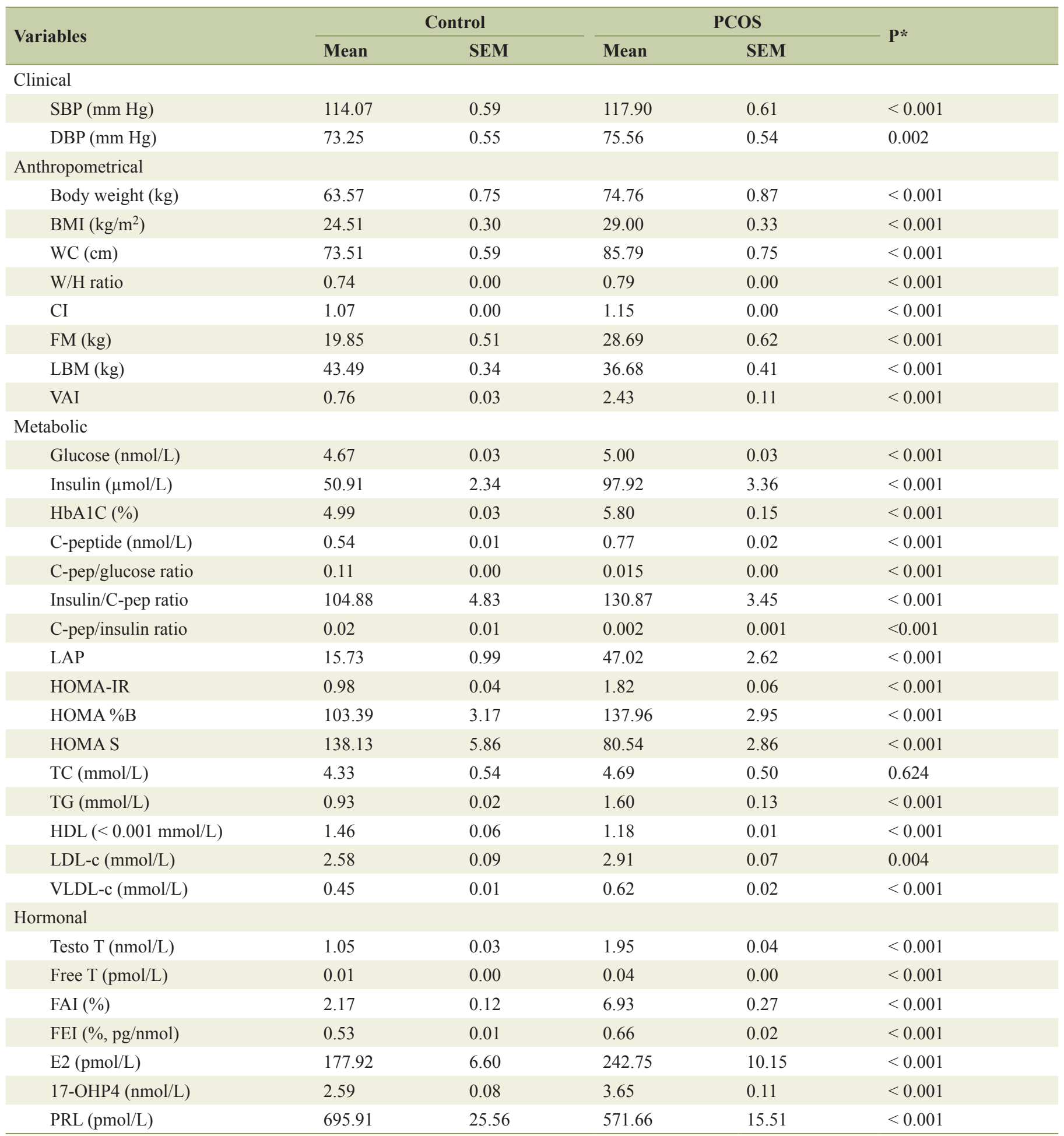

PCOS: polycystic ovary syndrome. *Pearson's correlation coefficient.

concentrations is presented in Table 2. The blood pressures, both the systolic and diastolic values, were significantly correlated with C-peptide in PCOS $(\mathrm{P}<0.001)$ but not in controls ( $\mathrm{P}$
$>0.05$ ). Using univariate linear regression of C-peptide with several anthropometrical variables (body weight, BMI, WC, $\mathrm{W} / \mathrm{H}$ ratio, $\mathrm{CI}$ and $\mathrm{VAI}$ ), remarkable correlations were found 
Table 2. Simple Correlation Between C-Peptide and Selected Clinical, Anthropometrical, Hormonal and Metabolic Cardiovascular Risk Markers in Polycystic Ovary Syndrome and Normal Cycling Women

\begin{tabular}{|c|c|c|c|c|}
\hline \multirow{2}{*}{ Variables } & \multicolumn{2}{|c|}{ PCOS } & \multicolumn{2}{|c|}{ Control } \\
\hline & $\mathbf{r}$ & $\mathbf{P *}$ & $\mathbf{r}$ & $\mathbf{P} *$ \\
\hline \multicolumn{5}{|l|}{ Clinical } \\
\hline $\mathrm{SBP}(\mathrm{mm} \mathrm{Hg})$ & 0.314 & 0.000 & 0.016 & 0.808 \\
\hline DBP (mm Hg) & 0.265 & 0.000 & 0.072 & 0.285 \\
\hline \multicolumn{5}{|l|}{ Anthropometrical } \\
\hline Body weight (kg) & 0.509 & 0.000 & 0.356 & 0.000 \\
\hline BMI $\left(\mathrm{kg} / \mathrm{m}^{2}\right)$ & 0.581 & 0.000 & 0.332 & 0.000 \\
\hline $\mathrm{WC}(\mathrm{cm})$ & 0.565 & 0.000 & 0.428 & 0.000 \\
\hline $\mathrm{W} / \mathrm{H}$ ratio & 0.459 & 0.000 & 0.258 & 0.000 \\
\hline CI & 0.353 & 0.000 & 0.240 & 0.000 \\
\hline $\mathrm{FM}(\mathrm{kg})$ & 0.549 & 0.000 & 0.376 & 0.000 \\
\hline LBM (kg) & 0.311 & 0.000 & 0.267 & 0.000 \\
\hline VAI & 0.539 & 0.000 & 0.317 & 0.000 \\
\hline \multicolumn{5}{|l|}{ Metabolic } \\
\hline Glucose (nmol/L) & 0.381 & 0.000 & 0.294 & 0.000 \\
\hline Insulin $(\mu \mathrm{mol} / \mathrm{L})$ & 0.602 & 0.000 & 0.621 & 0.000 \\
\hline $\mathrm{HbA1C}(\%)$ & 0.351 & 0.000 & 0.187 & 0.007 \\
\hline C-peptide (nmol/L) & - & - & - & - \\
\hline C-pep/glucose ratio & 0.967 & 0.000 & 0.974 & 0.000 \\
\hline Insulin/C-pep ratio & -0.164 & 0.002 & -0.231 & 0.002 \\
\hline C-pep/insulin ratio & 0.167 & 0.001 & 0.234 & 0.002 \\
\hline LAP & 0.434 & 0.000 & 0.433 & 0.000 \\
\hline HOMA-IR & 0.592 & 0.000 & 0.630 & 0.000 \\
\hline HOMA \%B & 0.445 & 0.000 & 0.387 & 0.000 \\
\hline HOMA S & -0.543 & 0.000 & -0.517 & 0.000 \\
\hline $\mathrm{TC}(\mathrm{mmol} / \mathrm{L})$ & 0.218 & 0.000 & 0.041 & 0.537 \\
\hline $\mathrm{TG}(\mathrm{mmol} / \mathrm{L})$ & 0.452 & 0.000 & 0.271 & 0.000 \\
\hline HDL (mmol/L) & -0.349 & 0.000 & -0.097 & 0.144 \\
\hline LDL-c (mmol/L) & 0.119 & 0.027 & -0.007 & 0.920 \\
\hline VLDL-c (mmol/L) & 0.418 & 0.000 & 0.404 & 0.000 \\
\hline \multicolumn{5}{|l|}{ Hormonal } \\
\hline Testo $\mathrm{T}(\mathrm{nmol} / \mathrm{L})$ & 0.182 & 0.000 & 0.018 & 0.782 \\
\hline Free F (pmol/L) & 0.322 & 0.000 & 0.146 & 0.027 \\
\hline FAI $(\%)$ & 0.457 & 0.000 & 0.250 & 0.000 \\
\hline $\mathrm{E} 2(\mathrm{pmol} / \mathrm{L})$ & 0.146 & 0.009 & 0.076 & 0.275 \\
\hline FEI $(\%, \mathrm{pg} / \mathrm{nmol})$ & 0.517 & 0.00 & 0.421 & 0.000 \\
\hline 17-OHP4 (nmol/L) & -0.036 & 0.486 & -0.079 & 0.238 \\
\hline PRL (pmol/L) & -0.191 & 0.000 & 0.115 & 0.087 \\
\hline
\end{tabular}

PCOS: polycystic ovary syndrome. *Pearson's correlation coefficient.

( $\mathrm{P}<0.001$ for all). FM and LBM were also significantly correlated with $\mathrm{C}$-peptide concentrations in both groups.

All markers of dysglycemia were also correlated with $\mathrm{C}$ - peptide in both PCOS patients and normal cycling controls (Table 2). Ratios between C-peptide and insulin were weakly but significantly correlated $(\mathrm{P}<0.05)$, but fasting $\mathrm{C}$-peptide/ fasting glucose ratio (fasting $\beta$ cell responsiveness) was highly and equally correlated in PCOS $(\mathrm{r}=0.967, \mathrm{P}<0.001)$ and controls $(\mathrm{r}=0.974, \mathrm{P}<0.001)$. The LAP was moderately correlated with $\mathrm{C}$-peptide levels in both groups. All of the lipids were also correlated with the C-peptide levels in PCOS but in normal cycling women, C-peptide was correlated only with TG and VLDL (Table 2). Total T, free testosterone and FAI were strongly correlated with $\mathrm{C}$-peptide concentrations in PCOS patients. In controls, C-peptide was correlated with free $\mathrm{T}$ and FAI but not with total T. Estradiol and PRL levels were correlated with C-peptide only in PCOS subjects.

In normal cycling women, the importance of these correlations for the clarification of the role of $\mathrm{C}$-peptide as marker of CVD risk was initially examined using a stepwise multiple regression with the inclusion of the significant simple correlation variables as predictors of $\mathrm{C}$-peptide levels. The significant emerged model retained C-peptide/glucose ratio, fasting glucose, and VAI as strong predictors of C-peptide (Table 3). This table shows that fasting C-peptide/glucose ratio was the single best predictor and glucose and VAI were the next best predictors of the criterion variable. So, C-peptide/glucose ratio as shown in model 1 (Table 3 ) accounted for $93.5 \%$ of the predictor variance. The inclusion of glucose and VAI into models 2 and 3 resulted in an additional $6.8 \%$ of the variance being explained as shown in the column $\mathrm{R}^{2}$ change of Table 3 . Therefore, the final model accounted for $99.3 \%$ of the variance (adjusted $\mathrm{R}^{2}=0.993$ ) and data indicated the strength of the model (adjusted $\mathrm{R}^{2}=0.993, \mathrm{~F}=38.33 \%, \mathrm{P}<0.001$ ). The non-standardized beta coefficients in the model 3 resulted in the following equation: C-peptide $=-0.503+4.763 \mathrm{C}$-peptide/ glucose ratio +0.104 glucose +0.011 VAI.

In PCOS, the stepwise multiple regression with the inclusion of the significant simple correlated variables as selected predictors of C-peptide levels, demonstrated that a significant model emerged from this examination, and the fasting C-peptide/glucose ratio, the fasting glucose, body weight, and FEI were retained as strong predictors of C-peptide (Table 4). In the final model, the inclusion of the fasting C-peptide/glucose ratio accounted for $97.4 \%$ of the C-peptide variance (adjusted $\left.\mathrm{r}^{2}=0.949\right)$. The inclusion of the fasting glucose, body weight, and FEI in the final model explained an additional $3.9 \%$ of the $\mathrm{C}$-peptide variance $\left(\mathrm{r}^{2}\right.$ change $\left.=0.001\right)$. Therefore, the final model accounted for $98.8 \%$ of the variance in the criterion variable $\left(\mathrm{F}=7.161, \mathrm{P}=0.000\right.$, adjusted $\left.\mathrm{r}^{2}=0.988\right)$. The non-standardized beta coefficient of each variable resulted in the following equation: C-peptide $=-0.722+5.148 \mathrm{C}$-peptide/ glucose ratio +0.159 glucose -0.001 body weight.

\section{Discussion}

C-peptide is considered to be a more reliable marker of pancreatic insulin-secretion, and the current study re-examined and expanded on previous knowledge regarding the use of C-peptide as a potential metabolic biomarker of CVD risk in PCOS 
Table 3. Stepwise Multiple Correlation Between C-Peptide and Known Predictors of Dysmetabolic Disease in Normal Cycling Women

\begin{tabular}{|c|c|c|c|c|c|c|c|c|}
\hline \multirow{2}{*}{ Model } & \multirow{2}{*}{$\mathbf{R}$} & \multirow{2}{*}{$\mathbf{R}^{2}$} & \multirow{2}{*}{ Adjusted $\mathbf{R}^{2}$} & \multirow{2}{*}{ Standard error of estimate } & \multicolumn{2}{|c|}{ Change statistics } & \multirow{2}{*}{ Sig. F change } & \multirow{2}{*}{ Durbin- Watson } \\
\hline & & & & & $\mathbf{R}^{2}$ change & F change & & \\
\hline 1 & $0.962 \mathrm{a}$ & 0.926 & 0.925 & 0.058021 & 0.935 & 962.028 & 0.000 & \\
\hline 3 & $0.997^{\mathrm{c}}$ & 0.994 & 0.993 & 0.173384 & 0.000 & $3,833.105$ & 0.000 & 1.979 \\
\hline
\end{tabular}

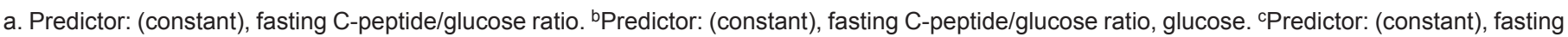
C-peptide/glucose ratio, glucose, VAI.

patients. C-peptide presented a strong correlation with other established markers of risk for vascular and metabolic diseases in the current study. To the best of our knowledge, there are no studies including clear clinical parameters on the investigation of the role of C-peptide in the development of CVD and T2DM in PCOS women. In the present study, blood pressures were strongly correlated with C-peptide concentrations in the whole group of PCOS patients. A few studies have demonstrated that C-peptide predicts the future development of dysmetabolic diseases in both non-PCOS and PCOS patients $[25,26]$. The increased concentration of C-peptide in PCOS reflects an increased pancreatic $\beta$-cell function [2]. Moreover, in addition to insulin resistance, pancreatic $\beta$-cell dysfunction, reflected by $\mathrm{C}$-peptide levels, is yet considered the second important risk factor to predict T2DM in PCOS [27]. As far as we know, no report on the possible association between blood pressure and C-peptide in PCOS women has been published. Furthermore, studies comparing C-peptide with other established clinical signs of T2DM and CVD in PCOS are lacking.

In a previous study, including non-PCOS subjects, C-peptide was highly associated with BMI and future T2DM development [10]. In non-diabetic, non-PCOS subjects, C-peptide was also associated with WC and body fat percentage, even after an adjustment for age, sex, insulin, and glucose levels [28]. Fasting C-peptide also showed a significant positive correlation with all of the anthropometric parameters in the present study. A positive correlation between C-peptide and BMI in PCOS was already reported [29], and C-peptide increased as BMI increased [30]. The mechanisms are not completely clear yet but it has been suggested that inflammatory cytokines play a significant role in patients with higher levels of C-peptide and a high BMI [30]. The strong correlations of C-peptide with $\mathrm{BMI}, \mathrm{WC}$ and the $\mathrm{W} / \mathrm{H}$ ratio found in the present study indicate that obesity is one of the major factors related to the increase in the $\beta$-cell function in PCOS women [31]. The possible effect of abdominal adipose tissue on $\beta$-cell function in other populations has been supported by experimental and clinical studies [30, 32].

Most of the dysglycemic biomarkers were well associated with $\mathrm{C}$-peptide in the present study $(\mathrm{P}<0.001$ for all). The fasting $\mathrm{C}$-peptide/insulin ratio presented a weak correlation with $\mathrm{C}$-peptide, and this weak correlation is a reflection of hepatic insulin extraction and the difference in the plasma half-lives of C-peptide and insulin. A good correlation between C-peptide, HOMA-IR, and serum insulin was previously demonstrated in PCOS patients [2]. The increase in C-peptide levels in PCOS indicates a worsened insulin resistance state with time [8]. In addition, C-peptide was strongly correlated with several biochemical markers of insulin resistance and fasting insulin levels in non-PCOS subjects [33]. The fasting C-peptide/fasting glucose molar ratio and the fasting $\beta$ cell responsiveness index are considered to be the most valuable parameters for estimating $\beta$-cell function. In the current study, this index showed the strongest correlation with C-peptide $(\mathrm{r}=0.967)$. The insulinogenic index, a surrogate for early insulin secretion was not correlated with C-peptide levels in the present study, but it tended to increase as in BMI increased (data not shown). In a previous study, this index was not different for any of the BMI groups [30], clearly suggesting that in PCOS insulin is not a good marker of $\beta$-cell dysfunction.

Even in the present study, C-peptide was strongly correlated with the different lipids $(\mathrm{P} \leq 0.001)$, and the correlations were strongest with TG, VLDL-c and HDL-c. Consistent with the present study, higher levels of TC and TG, and lower levels of HDL-c were common findings in PCOS women, mainly in those with IGT [34]. Dyslipidemia has been closely related to

Table 4. Stepwise Multiple Regression Between C-Peptide and Known Predictors of Dysmetabolic Disease in Patients With Polycystic Ovary Syndrome

\begin{tabular}{|c|c|c|c|c|c|c|c|c|}
\hline \multirow{2}{*}{ Model } & \multirow{2}{*}{$\mathbf{R}$} & \multirow{2}{*}{$\mathbf{R}^{2}$} & \multirow{2}{*}{ Adjusted $\mathbf{R}^{2}$} & \multirow{2}{*}{ Standard error of estimate } & \multicolumn{2}{|c|}{ Change statistics } & \multirow{2}{*}{ Sig. F change } & \multirow{2}{*}{ Durbin- Watson } \\
\hline & & & & & $\mathbf{R}^{2}$ change & F change & & \\
\hline 1 & $0.974 \mathrm{a}$ & 0.950 & 0.949 & 96.09569 & 0.950 & $2,884.299$ & 0.000 & \\
\hline 3 & $0.994^{\mathrm{c}}$ & 0.988 & 0.988 & 47.50930 & 0.001 & 8.345 & 0.004 & \\
\hline 4 & $0.994^{\mathrm{d}}$ & 0.988 & 0.988 & 46.56880 & 0.001 & 7.161 & 0.008 & 2.031 \\
\hline
\end{tabular}

a. Predictor: (constant), fasting C-peptide/glucose ratio. bPredictor: (constant), fasting C-peptide/glucose ratio, glucose. ${ }^{\mathrm{c} P r e d i c t o r: ~(c o n s t a n t), ~ f a s t i n g ~}$

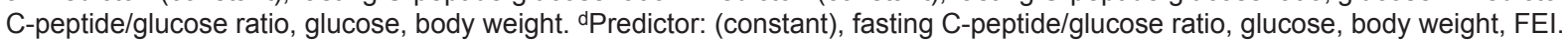


obesity in PCOS [35]. Higher TG concentrations were previously found in overweight and obese PCOS patients [36]. In another study, TG was correlated with WC and BMI [37]. The LAP index was associated with C-peptide levels in the whole group of PCOS patients in the current study and the correlation of LAP, and HOMA-IR, were reported in recent studies as a good index to detect IR [38].

Among androgens, the total $\mathrm{T}$, free $\mathrm{T}$, and FAI were strongly and positively correlated with C-peptide levels. This positive correlation between C-peptide and the free and total $\mathrm{T}$ levels had already been demonstrated in PCOS [32], indicating a functional relationship between hyperandrogenemia and the functional capacity of pancreatic $\beta$ cells. In a recent small study, no correlation was found between C-peptide and androgens in overweight and obese subjects [39], even though an association between insulin resistance and the hyperandrogenic state in PCOS has been described for decades [40]. Furthermore, it is well established that insulin facilitates androgen synthesis and secretion and decreases SHBG while increasing the free fraction of androgens [2].

C-peptide has been considered a better predictor of CVD and overall mortality than other known markers of IR and metabolic syndrome in non-PCOS subjects [33]. In addition, C-peptide levels may predict the future worsening of the other risk factors or the future development of T2DM and CVD [27]. A prediction model for C-peptide concentrations in PCOS patients was constructed in the present study, and it demonstrated that the C-peptide/glucose ratio, body weight, and FEI were the best biological markers of C-peptide concentrations in PCOS. Insulin levels were excluded in this model.

Despite the fact that the current study has revisited and expanded on the role of C-peptide as a metabolic marker of potential risk for T2DM and CVD in PCOS subjects, a few limitations have to be considered. The examination of only anthropometrical data and blood pressure as clinical parameters for the risk of T2DM and CVD should be considered. The influence of confounding obesity, other residual confounding factors, such as time of disease and life style were not controlled. The main concern with the imprecise androgen measurement in women was attenuated by providing extensive details regarding the imprecision and sensitivity of the assays used. Furthermore, recent comparisons between the current assays for sex steroids and liquid chromatography tandem have demonstrated good agreement between methods [41]. The strengths of this study include an objective exclusion of all of the hyperandrogenic conditions, eliminating some potential confounders and, demonstrating that most of variables worsen with adiposity.

The current study provides support for the hypothesis that the fasting C-peptide concentration is at least comparable to other already known predictors of T2DM and CVD and can be used as a sensitive biomarker in PCOS patients. These findings also made clear that, in PCOS women, obesity determines a higher demand in pancreatic $\beta$-cell function. A stepwise multiple regression analysis showed that the best independent predictors for C-peptide concentrations in PCOS were the fasting C-peptide/fasting glucose ratio, fasting glucose, body weight and FEI. Thus, this final model significantly improves the ability of the outcome variable C-peptide. In addition, the increase in C-peptide levels with age and anthropometrical parameters indicates a worsened $\beta$-cell function with time. Future studies, including objective vascular and endothelial examination, will be necessary to prove the utility of C-peptide as a simple marker of dysmetabolism and CVD risk in PCOS women.

\section{Acknowledgments}

American Journal Experts.

\section{Conflict of Interest}

The authors fully declare there is no financial or other conflict of interest.

\section{Author Contributions}

Sebastiao Freitas de Medeiros: design, data's description, statistical analysis, and writing the manuscript. Laura Camila Antunes Angelo: data search, revision of the manuscript. Matheus Antonio Souto de Medeiros: data search, revision of the manuscript. Camila Regis Banhara: data search, data's presentation, revision of the manuscript. Bruna Barcelo Barbosa: data search, and revision of the manuscript. Márcia Marly Winck Yamamoto: data search, and revision of the manuscript.

\section{Funding}

This research did not receive any specific grant from any funding agency.

\section{References}

1. Rosenfield RL, Ehrmann DA. The Pathogenesis of Polycystic Ovary Syndrome (PCOS): The hypothesis of PCOS as functional ovarian hyperandrogenism revisited. Endocr Rev. 2016;37(5):467-520.

2. Dunaif A. Insulin resistance and the polycystic ovary syndrome: mechanism and implications for pathogenesis. Endocr Rev. 1997;18(6):774-800.

3. Steiner DF. The proinsulin C-peptide - a multirole model. Exp Diabesity Res. 2004;5(1):7-14.

4. Saisho Y. Postprandial C-Peptide to Glucose Ratio as a Marker of beta Cell Function: Implication for the Management of Type 2 Diabetes. Int J Mol Sci. 2016;17(5):744.

5. Wahren J, Shafqat J, Johansson J, Chibalin A, Ekberg K, Jornvall H. Molecular and cellular effects of C-peptidenew perspectives on an old peptide. Exp Diabesity Res. 2004;5(1):15-23.

6. Luppi P, Cifarelli V, Tse H, Piganelli J, Trucco M. Human C-peptide antagonises high glucose-induced endothelial dysfunction through the nuclear factor-kappaB pathway. 
Diabetologia. 2008;51(8):1534-1543.

7. Marx N, Walcher D, Raichle C, Aleksic M, Bach H, Grub M, Hombach V, et al. C-peptide colocalizes with macrophages in early arteriosclerotic lesions of diabetic subjects and induces monocyte chemotaxis in vitro. Arterioscler Thromb Vasc Biol. 2004;24(3):540-545.

8. Kim ST, Kim BJ, Lim DM, Song IG, Jung JH, Lee KW, Park KY, et al. Basal C-peptide level as a surrogate marker of subclinical atherosclerosis in type 2 diabetic patients. Diabetes Metab J. 2011;35(1):41-49.

9. Sari R, Balci MK. Relationship between C peptide and chronic complications in type-2 diabetes mellitus. J Natl Med Assoc. 2005;97(8):1113-1118.

10. Marx N, Silbernagel G, Brandenburg V, Burgmaier M, Kleber ME, Grammer TB, Winkelmann BR, et al. C-peptide levels are associated with mortality and cardiovascular mortality in patients undergoing angiography: the LURIC study. Diabetes Care. 2013;36(3):708-714.

11. Wang L, Lin P, Ma A, Zheng H, Wang K, Li W, Wang C, et al. C-peptide is independently associated with an increased risk of coronary artery disease in T2DM subjects: a cross-sectional study. PLoS One. 2015;10(6):e0127112.

12. Jones AG, Hattersley AT. The clinical utility of C-peptide measurement in the care of patients with diabetes. Diabet Med. 2013;30(7):803-817.

13. Rotterdam EA-SPCWG. Revised 2003 consensus on diagnostic criteria and long-term health risks related to polycystic ovary syndrome. Fertil Steril. 2004;81(1):1925.

14. de Medeiros SF, Barbosa JS, Yamamoto MM. Comparison of steroidogenic pathways among normoandrogenic and hyperandrogenic polycystic ovary syndrome patients and normal cycling women. J Obstet Gynaecol Res. 2015;41(2):254-263.

15. de Medeiros SF, Barbosa JS, de Medeiros MA, da Silva EB, de Souza AC, Yamamoto MM. Is glycated hemoglobin related to other dysmetabolic variables implicated in the increase of cardiovascular risk in polycystic ovary syndrome? A comparative study. Exp Clin Endocrinol Diabetes. 2014;122(9):1-5.

16. de Medeiros SF, Ormond CM, de Medeiros MAS, de Souza Santos N, Banhara CR, Yamamoto MMW. Metabolic and endocrine connections of 17-hydroxypregnenolone in polycystic ovary syndrome women. Endocr Connect. 2017;6(7):479-488.

17. WHO Consultion on obesity. Obesity: preventing and managing the global epidemic. Report of a World Health Organization C'onsultation. World Health Organization Technical Report Series 894. Geneva: World Health Organization, 2000.

18. Amato MC, Giordano C. Visceral adiposity index: an indicator of adipose tissue dysfunction. Int J Endocrinol. 2014;2014:730827.

19. McAuley KA, Williams SM, Mann JI, Walker RJ, Lewis-Barned NJ, Temple La, Duncan AW. Diagnosis insulin resistance in the general population. Diabetes Care. 2001;24(3):460-464.

20. Geloneze B, Vasques AC, Stabe CF, Pareja JC, Rosado LE, Queiroz EC, Tambascia MA, et al. HOMA1-IR and HOMA2-IR indexes in identifying insulin resistance and metabolic syndrome: Brazilian Metabolic Syndrome Study (BRAMS). Arq Bras Endocrinol Metabol. 2009;53(2):281-287.

21. Matthews DR, Hosker JP, Rudenski AS, Naylor BA, Treacher DF, Turner RC. Homeostasis model assessment: insulin resistance and beta-cell function from fasting plasma glucose and insulin concentrations in man. Diabetologia. 1985;28(7):412-419.

22. Hovorka R, Chassin L, Luzio SD, Playle R, Owens DR. Pancreatic beta-cell responsiveness during meal tolerance test: model assessment in normal subjects and subjects with newly diagnosed noninsulin-dependent diabetes mellitus. J Clin Endocrinol Metab. 1998;83(3):744-750.

23. Friedewald WT, Levy RI, Fredrickson DS. Estimation of the concentration of low-density lipoprotein cholesterol in plasma, without use of the preparative ultracentrifuge. Clin Chem. 1972;18(6):499-502.

24. Kahn HS, Valdez R. Metabolic risks identified by the combination of enlarged waist and elevated triacylglycerol concentration. Am J Clin Nutr. 2003;78(5):928-934.

25. Wild RA, Carmina E, Diamanti-Kandarakis E, Dokras A, Escobar-Morreale HF, Futterweit W, Lobo R, et al. Assessment of cardiovascular risk and prevention of cardiovascular disease in women with the polycystic ovary syndrome: a consensus statement by the Androgen Excess and Polycystic Ovary Syndrome (AE-PCOS) Society. J Clin Endocrinol Metab. 2010;95(5):2038-2049.

26. Mani H, Levy MJ, Davies MJ, Morris DH, Gray LJ, Bankart J, Blackledge H, et al. Diabetes and cardiovascular events in women with polycystic ovary syndrome: a 20-year retrospective cohort study. Clin Endocrinol (Oxf). 2013;78(6):926-934.

27. Cassar S, Teede HJ, Harrison CL, Joham AE, Moran LJ, Stepto NK. Biomarkers and insulin sensitivity in women with Polycystic Ovary Syndrome: Characteristics and predictive capacity. Clin Endocrinol (Oxf). 2015;83(1):5058.

28. Hanley AJ, McKeown-Eyssen G, Harris SB, Hegele RA, Wolever TM, Kwan J, Zinman B. Cross-sectional and prospective associations between abdominal adiposity and proinsulin concentration. J Clin Endocrinol Metab. 2002;87(1):77-83.

29. Battaglia C, Mancini F, Cianciosi A, Busacchi P, Facchinetti F, Marchesini GR, Marzocchi R, et al. Vascular risk in young women with polycystic ovary and polycystic ovary syndrome. Obstet Gynecol. 2008;111(2 Pt 1):385395.

30. Maliqueo M, Atwater I, Lahsen R, Perez-Bravo F, Angel B, Sir-Petermann T. Proinsulin serum concentrations in women with polycystic ovary syndrome: a marker of beta-cell dysfunction? Hum Reprod. 2003;18(12):26832688.

31. Prelevic GM, Wurzburger MI, Peric LA. Pancreatic beta cell function in polycystic ovary syndrome: its relationship to body weight, serum testosterone and serum prolactin levels. Exp Clin Endocrinol. 1987;90(1):76-82.

32. Abate N. Insulin resistance and obesity. The role of fat distribution pattern. Diabetes Care. 1996;19(3):292-294. 
33. Patel N, Taveira TH, Choudhary G, Whitlatch H, Wu WC. Fasting serum C-peptide levels predict cardiovascular and overall death in nondiabetic adults. J Am Heart Assoc. 2012;1(6):e003152.

34. Talbott E, Guzick D, Clerici A, Berga S, Detre K, Weimer K, Kuller L. Coronary heart disease risk factors in women with polycystic ovary syndrome. Arterioscler Thromb Vasc Biol. 1995;15(7):821-826.

35. Valkenburg O, Steegers-Theunissen RP, Smedts HP, Dallinga-Thie GM, Fauser BC, Westerveld EH, Laven JS. A more atherogenic serum lipoprotein profile is present in women with polycystic ovary syndrome: a case-control study. J Clin Endocrinol Metab. 2008;93(2):470-476.

36. Godinjak A, Godinjak Z, Burekovic A, Surkovic I, Dizdarevic-Bostandzic A, Velija-Asimi Z. Insulin resistance and lipid accumulation product in corelation to body mass index in women with polycystic ovary syndrome. Med Arch. 2012;66(6):409-411.

37. Iuhas CI, Costin N, Mihu D. Lipid parameters in pa- tients with polycystic ovary syndrome. Appl Med Inform. 2012;31(4):27-32.

38. Wehr E, Gruber HJ, Giuliani A, Moller R, Pieber TR, Obermayer-Pietsch B. The lipid accumulation product is associated with impaired glucose tolerance in PCOS women. J Clin Endocrinol Metab. 2011;96(6):E986-990.

39. Maciejewska-Jeske M, Szczesna A, Meczekalski B. [Serum $\mathrm{C}$-peptide concentration in overweight and obese women with polycystic ovary syndrome]. Pol Merkur Lekarski. 2010;29(170):93-99.

40. Burghen GA, Givens JR, Kitabchi AE. Correlation of hyperandrogenism with hyperinsulinism in polycystic ovarian disease. J Clin Endocrinol Metab. 1980;50(1):113116.

41. Legro RS, Schlaff WD, Diamond MP, Coutifaris C, Casson PR, Brzyski RG, Christman GM, et al. Total testosterone assays in women with polycystic ovary syndrome: precision and correlation with hirsutism. J Clin Endocrinol Metab. 2010;95(12):5305-5313. 